\title{
官民の役割分担に関する情報の 経済学からのアプローチ
}

石 坂 元一

\section{ロアブストラクト}

本稿は，医療保険市場を対象に，情報の非対称性から生じるモラル・八ザ 一ドと逆選択への対処策の有効性をモデルの上で示し，官民の役割分担の意 義とその在り方を検討するものである。いずれの問題に対しても契約内容を 工夫することで対処策が講じられ，その効果を定量的に算出することができ るものの，両者を同時に解決できる最善策は存在しない。しかし，逆選択へ の対処策を官民の役割分担に応用することで，パレート改善を達成できる可 能性が示される。ここから役割分担の意義と在り方への手掛かりを得ること ができる。ただし，とりわけ医療サービスにおいては，資源配分の効率性だ けではなく公平性もまた重視される。医療サービスに関して, 官には公的保 険以外の介入手段も含好熟慮する必要があり, 民間保険には一層多様な役 割が期待される。

ロキーワード

モラル・ハザード，逆選択，官民の役割分担

\section{1.はじめに}

情報の非対称性から生じる問題が扱われる際には, 各主体が保有する情報 の差異に着目して，しばしば保険市場が取り上げられる。また，医療保険市

*平成25年10月26日の日本保険学会（愛知学院大学）報告による。

/ 平成26年 6 月 11 日原稿受領。 
官民の役割分担に関する情報の経済学からのアプローチ

場においては，そもそも医療サービス自体が高い専門性を帯びており，他の 財やサービスより需給者間の情報の非対称性が大きい。加えて, 医療保険市 場を構成する登場人物が, 少なくとも契約者 (加入者), 保険者（私法人・ 公法人）および医療サービス提供者の三者存在している点も特徵的であろう。

情報の非対称性から生じる問題としては，よく知られた逆選択とモラル． ハザードが挙げられる。これらについて保険市場を対象に分析した先行研究 は国内外で数多く見られ, 情報の経済学, 医療経済学, 社会保障分野等で頻 繁に論じられるところである。そこでは，逆選択が問題となるとき，わが国 で強制加入が義務付けられている公的医療保険をはじめとして，政府の介入 が正当化されることがある。しかし，強制加入であってもモラル・八ザード の問題は回避されるわけではない。ゆえに官民の役割分担について，二つの 問題を同時に解消するような最善の解は存在せず，いくつかの基準の下での 次善の解がそれぞれ提示されうる。基準を設ける際のキーワードは効率性と 公平性の二つであるが，これらはまたしばしばトレードオフの関係にある。

本稿では，医療保険市場における保険者と契約者（加入者）間の情報の非 対称性に絞り，そこから生じる逆選択やモラル・ハザードの問題を整理し， 官民の役割分担を論ずることを目的とする。具体的には，役割分担の意義や， ある基準の下での望ましい官民それぞれのカバー領域を論ずることである。

本稿の構成は次の通りである。第 2 節では, 完全情報の下での契約者（加

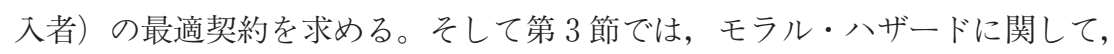
契約者に自己負担を課すことにより保険事故の頻度と強度，余利のいずれも 改善が見られることを示す。また第 4 節では. 逆選択に関して, 結果として 引き起こされる市場の崩壊，および対処策の一つであるスクリーニング（自 己選抜）を促す分離均衡を紹介する。第 5 節では, 公的医療保障制度を意識 して，平均保険料を適用した強制保険の導入を整理する。前述のように，こ れは逆選択の解消そして医療アクセスの公平性から見て有効であることが明 らかである。しかしながら，非効率やモラル・ハザードの問題は残る。第 6 節では，Zweifel（2000）の議論を基に官民の役割分担を決定する手掛かり 
を求め, さらに公平性の観点からもアプローチを試みる。最後に第 7 節では 考察と課題を述べる。

\section{2. 完全情報下での均衡}

本節では，後の議論のベースとなる完全情報下での均衡について概略を説 明する。

\section{$2-1$. リスク・タイプ 1 種類}

まず，契約者はリスク回避的であり，期待効用最大化を行動原理とする。 ここではリスク・タイプは 1 種類のみと仮定するため, 同一の効用関数 $u$ $\left(u^{\prime}>0, u^{\prime \prime}<0, u^{\prime \prime \prime}>0\right)$ を持つ。契約者は疾病率 $p(0<p<1)$ で疾病の リスクに酔されており，疾病時には $M(>0)$ の治療コストがかかるものと する。初期所得を $w(\geq M)$ とし，将来は健康と疾病の 2 状態いずれかを とり，事後所得をそれぞれ， $W_{1}, W_{2}$ と記す。契約者が最大化を目指す期待 効用は以下のように表される。

$$
E U=(1-p) u\left(W_{1}\right)+p u\left(W_{2}\right)
$$

今，治療費に対して $\alpha(0 \leq \alpha \leq 1)$ の割合のカバーを提供する契約が提 示されているものとする。保険料は，フルカバーすなわち $\alpha=1$ のとき $x(0 \leq x \leq M)$ とし，カバー割合に比例する。よって，保険契約者の事後 所得は以下のように表される。

$$
\left\{\begin{array}{l}
W_{1}=w-\alpha x \\
W_{2}=w-\alpha x-M+\alpha M
\end{array}\right.
$$

この保険を提供する保険者はリスク中立的であり，当該保険市場は完全競 争的であると仮定する。よって，保険者は期待利潤がゼロになる保険料水準 で契約を提示する。保険者の期待利潤は， 
官民の役割分担に関する情報の経済学からのアプローチ

$$
E \Pi=(1-p) \alpha x+p(\alpha x-\alpha M)
$$

と表されるので，これをゼロと置くことにより $x=p M$ が得られる。この 水準は保険数理的に公正な保険料水準である。また，(2)式および(3)式と合わ せると，以下の fair odds lineを表す式が得られる11。

$$
(1-p) W_{1}+p W_{2}=w-p M
$$

保険者はこの線上で契約を提示するならば，期待利潤がゼロであるから，収 支相等が見込める。

以上の設定から，契約者にとっての最適な保険カバ一範囲を求める。つま り，(5)式を制約として(1)式の期待効用を最大化する $\alpha$ を導出する。 1 階の 条件 $\frac{\partial E U}{\partial \alpha}=0$ より $u^{\prime}\left(W_{1}\right)=u^{\prime}\left(W_{2}\right)$ が得られ, $u$ の仮定から $W_{1}=W_{2}$ と なる。ゆえに， $\alpha=1$ すなわちフルカバーの保険（完全保険）が最適水準と して選択される。

このことは図 1 からも確認できる。まず fair odds line と名付けられた右 下がりの直線が制約式を表している。前述のように，この線上であれば保険 者の期待収支は均衡する ${ }^{2}$ 。 fair odds lineの傾きは $-\frac{1-p}{p}$ であり，必ず 点 $N$ を通る。この点の座標は $(w, w-M)$ であり，保険未加入時の事後所 得の組み合わせを表す。罒中で最適な契約は点 $E$ によって示されている。 点 $N$ を通る無差別曲線を出発として考えると, 保険に加入しカバーを増し ていくほど当該点を通る無差別曲線は右上に位置し，ゆえに効用が増してい く。制約の下での最も高い効用は無差別曲線と fair odds line が接する点 $E$ で達成される ${ }^{3)}$ 。点 $E$ は傾き 1 の点線上にあるため, 健康時と疾病時いず

1）所得線，予算線，機会線，契約線などとも呼ばれる。本稿では保険数理的に 公正な保険料や保険者の収支均衡の意味を込めて fair odds line の呼び名を用 いる。

2）この線より右上の範囲では保険者の収支はマイナス，左下ではプラスである。

3）無差別曲線の接線の傾きは, $\frac{d W_{2}}{d W_{1}}=-\frac{(1-p) u^{\prime}\left(W_{1}\right)}{p u^{\prime}\left(W_{2}\right)}$ である。 
れも同じ所得を実現させるフルカバーの保険加入を表している。

\section{図 1.完全情報下での均衡；リスク1タイプ}

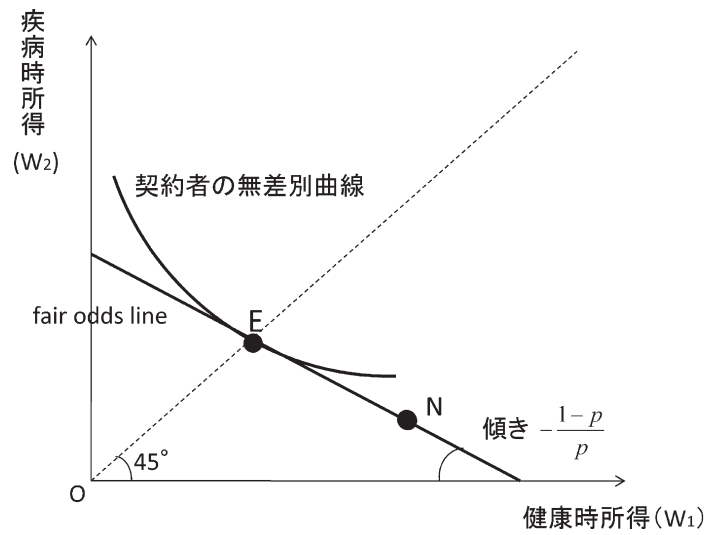

\section{$2-2$. リスク・タイプ 2 種類}

次に，リスク・タイプを 2 種類に増やした場合の均衡を考える。疾病に関 して低リスクのタイプ Lと高リスクのタイプHの 2 種類が存在しており，そ れぞれの疾病率を $p_{L}$ と $p_{H}\left(0<p_{L}<p_{H}<1\right)$ とする ${ }^{4)}$ 。また，完全情報で あるため，保険者は契約者のリスク・タイプを完全に識別できると仮定する。 この場合，前述のリスク・タイプが 1 種類のケースを容易に拡張して最適な 保険力バ一範囲を求めることができる。結論は図 2 に示されている通り, 点 $E_{L}$ と点 $E_{H}$ が (分離) 均衡となりうる。タイプLに関してはグレーで表さ れており，低リスクゆえに fair odds lineの勾配が大きい。保険者がリス ク・タイプを識別できるため，タイプ L $(\mathrm{H})$ に対してはそのリスクに見合 った保険料水準で保険契約が提示される。その結果，どちらの夕イプもフル カバーの保険契約が可能となり，それらが均衡となる5)。

4）他の設定はリスク・タイプ1 種類のときと同様とする。

5）各 fair odds line 上での契約であるから，保険者の期待収支もゼロである。 
官民の役割分担に関する情報の経済学からのアプローチ

\section{図 2.完全情報下での（分離）均衡; リスク 2 タイプ}

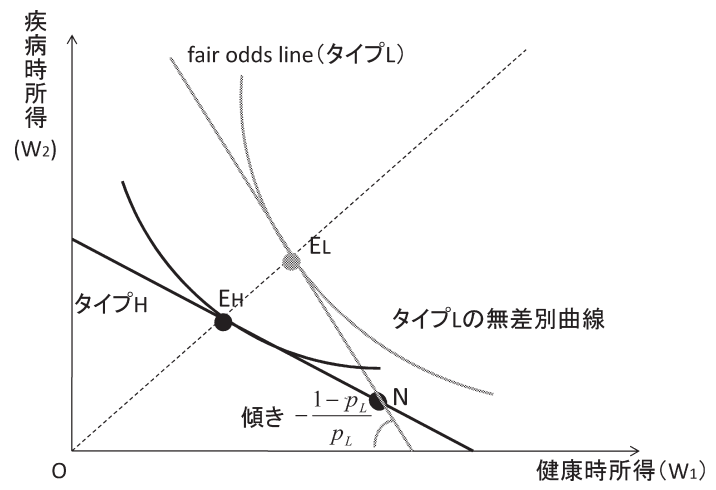

\section{3. モラル・ハザードへの対処策}

本節では情報の非対称性から生じるモラル・ハザードの問題を扱う。モラ ル・ハザードとは, ある契約が経済主体の行動を変化させてしまう現象を指 す。ゆえに, 契約締結後の情報の非対称性から生じる現象とも, 保険者が被 保険者（ここでは契約者と同一と見なす）の行動を完全に監視できないこと から生じる現象とも説明される。

保険契約にモラル・ハザードはつきものであり，保険契約を結ぶことによ り様々な負の影響を及ぼすことが知られている。つまり，保険は，契約者に 保険事故の頻度および強度をコントロール可能な範囲で大きくしてしまう誘 因を与え，また余剰の観点からは総余剰を減少させてしまう結果を招く。医 療保険に照らすと，保険事故の頻度とは疾病率に，強度とは治療コス卜や医 療サービス量に相当する。

こういったモラル・ハザードの問題への対処策としては，契約者に自己負 担を課すリスク・シェアリングが有効であるとされる。そこで，本節では， 自己負担がモラル・ハザードの改善に寄与することを前節のリスク・タイプ 1 種類のモデルを基に，頻度，強度および余剰の各観点から示すこととする。 なお，自己負担の方法として定率負担と定額負担があるが，ここでは前者に 
よる改善を提示する6)

\section{$3-1$. 頻度の観点から}

ここでは契約者が頻度（疾病率）をある程度コントロールできることを想 定する。ただし，疾病率を下げるために努力や投資を行うことから契約者の 効用が幾分減少すると考えられる。そこで，疾病率を抑制するために払う効 用コストの関数を $c(p)\left(c^{\prime}<0, c^{\prime \prime}>0\right)$ とする。さらに，保険者が保険料

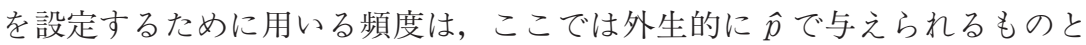
する。保険カバー割合として $\alpha$ と $\beta(0<\alpha<\beta<1)$ の 2 種類を導入し, 契約者が行動原理にしたがって頻度を選択したとき，自己負担割合の大きな 契約設計の方がより頻度が小さくなることを示していく。

カバー割合 $\alpha$ のケース，つまり疾病時の保険者によるカバーが $\alpha M$ であ $\eta$ ，契約者の自己負担が $(1-\alpha) M$ である場合，事後所得は以下のように 表される。

$$
\left\{\begin{array}{l}
W_{1}=w-\alpha \hat{p} M \\
W_{2}=w-\alpha \hat{p} M-(1-\alpha) M
\end{array}\right.
$$

$$
\begin{aligned}
& \frac{\partial E U}{\partial p}=0 \text { より, } \\
& \quad c^{\prime}{ }_{\alpha}(p)=-u(w-\alpha \hat{p} M)+u(w-\alpha \hat{p} M-(1-\alpha) M)
\end{aligned}
$$

が得られる。カバー割合 $\beta$ についても(8)式と全く同様の $c^{\prime}{ }_{\beta}(p)$ が求められ る7)。ここで, $w-\alpha \hat{p} M>w-\beta \hat{p} M>w-\beta \hat{p} M-(1-\beta) M>w-\alpha \hat{p} M-$ $(1-\alpha) M$ であるから， $u$ の仮定より $c^{\prime}{ }_{\alpha}(p)<c^{\prime}{ }_{\beta}(p)$ となる。したがって， $c$ の仮定より $p_{\alpha}{ }^{*}<p_{\beta}{ }^{*}$ となり，自己負担割合が大きな場合に小さな頻度が 選択される。つまり，自己負担割合の大きな契約設計の方が，効用減少分を

6）定額負担については，定率負担とほぼ同様のプロセスで改善寄与度を示すこ とができるため，本稿では割愛する。

7）形式的に $\alpha$ を $\beta$ に置き換えたものとなる。 
官民の役割分担に関する情報の経済学からのアプローチ

考慮したとしても疾病率を抑える努力や投資を行う誘因をもたらすことが示 された。

\section{$3-2$. 強度の観点から}

ここでは自己負担が治療費や医療サービス量の抑制効果を持つことを，フ ルカバーの保険と一部カバーの保険を比較することにより示していく。前小 節の頻度同様に，強度についても治療費抑制を実現するために払う効用コス トの関数を $c(p)\left(c^{\prime}<0, c^{\prime \prime}>0\right)$ とする。

カバー割合 $\alpha$ の場合, 事後所得は以下のように表される。

$$
\left\{\begin{array}{l}
W_{1}=w-\alpha p M \\
W_{2}=w-\alpha p M-(1-\alpha) M
\end{array}\right.
$$

$\frac{\partial E U}{\partial M}=0$ より,

$$
\begin{aligned}
c^{\prime}{ }_{a}(M)= & -\alpha p(1-p) u^{\prime}(w-\alpha p M)-p(1-\alpha(1-p)) u^{\prime}(w-\alpha p M- \\
& (1-\alpha) M)
\end{aligned}
$$

が得られる。同様にしてフルカバーの場合，

$$
c_{F}^{\prime}(M)=-p u^{\prime}(w-p M)
$$

と求められるため,

$$
\alpha(1-p) u^{\prime}\left(W_{1}\right)+(1-\alpha(1-p)) u^{\prime}\left(W_{2}\right)>u^{\prime}(w-p M)
$$

を示すことができれば題意が証明される。ただし， $W_{1}$ と $W_{2}$ は(9)式と(10)式 で定義される一部力バー時の事後所得である。ここで,

$$
W_{3}=\alpha(1-p) W_{1}+(1-\alpha(1-p)) W_{2}
$$

と置く。 $W_{3}$ は $W_{1}$ と $W_{2}$ を $\alpha(1-p):(1-\alpha(1-p))$ に内分する点である。 $W_{3}<w-p M$ および $u$ の仮定より， 


$$
\alpha(1-p) u^{\prime}\left(W_{1}\right)+(1-\alpha(1-p)) u^{\prime}\left(W_{2}\right)>u^{\prime}\left(W_{3}\right)>u^{\prime}(w-p M)
$$

が得られる。よって，(13)式が成立し， $c$ の仮定より $M_{\alpha}{ }^{*}<M_{F}{ }^{*}$ となる。つ まり一部カバー（自己負担あり）の方が契約者に治療費抑制に対する努力や 投資を行わせることが示された。

\section{$3-3$. 余剩の観点から}

ここでは簡単な部分均衡分析を用いて余剩減少（厚生損失）の観点から述 べる。

図 3 は医療サービス市場の需給を描いたものである。簡単化のため，医療 サービス価格は限界費用に等しいものとしている。医療保険が存在しない場 合は，需要は OX の水準で決定され，総余剩（=消費者余剩）は $\triangle \mathrm{AED}$ と なる。フルカバーの医療保険が付加的コストなしで提供されるならば，需要 水準は $\mathrm{OZ}$ まで増大し，消費者余剩は $\triangle \mathrm{OZD}$ から保険料支払分の $\square \mathrm{OZCA}$ を差し引いたものに減じられる。つまり， $\triangle \mathrm{ECZ}$ だけ厚生損失が生じてい る。次に $\mathrm{OA}^{\prime}$ まで契約者に自己負担を課すとすると, 均衡需要水準は OY になり，消費者余剩は $\triangle \mathrm{A}^{\prime} \mathrm{E}^{\prime} \mathrm{D}$ から $\square \mathrm{A}^{\prime} \mathrm{E}^{\prime} \mathrm{BA}$ を差し引いたものとして表さ

図 3 . 医療サービスの需給と総余剩

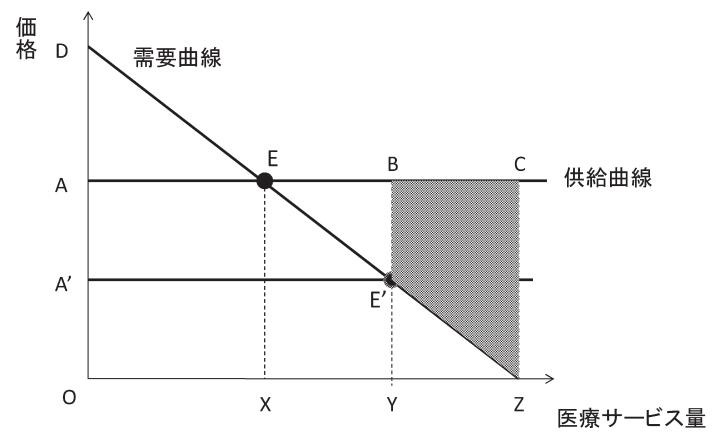


官民の役割分担に関する情報の経済学からのアプローチ

れる ${ }^{8)}$ 。フルカバーと一部カバーを比較すると, 後者の方が図中で塗りつぶ されている台形 $E^{\prime} Z C B$ 分だけ余剰が改善されている。

ただし，余剰減少やその改善度合いは医療サービスに対する需要の価格弾 力性に大きく依存している。軽度な疾病から重篤なものまで医療サービスに 対する弾力性は様々であるから，それに反応する余㮃減少（厚生損失）もま た異なってくる。厚生損失の観点からは, 価格弾力性の小さな医療サービス の自己負担を相対的に下げた方が効率的であると言える。

\section{4 . 逆選択への対処策}

情報の非対称性を原因とするもう一つの問題は逆選択である。取引者間の 情報の偏りから望ましい財・サービスが取引されないようになり，終には市 場の崩壊をも招きかねない。契約締結前の情報の非対称性から生じる現象と も，保険者が被保険者（契約者と同一と見なす）のリスク・タイプを識別す ることができないことから生じる現象とも説明される。

もし保険者が契約者のリスク・タイプを完全に識別できるならば，第 2 節 で四示したように，低リスク・タイプLと高リスク・タイプHとそれぞれの リスクに応じた保険料でフルカバーの保険を契約することにより均衡が達成 される。しかし，実際には保険者が契約者のリスク・タイプを完全に識別す ることは不可能である。仮にリスク・タイプを識別できないまま保険者が 2 種類の保険契約を提示するならば，タイプ $\mathrm{H} も$ 含めて皆が保険料の安い夕イ プL向けの保険契約に引きつけられよう。四 2 の点 $E_{L}$ は夕イプ Hに対する fair odds lineよりも右上に位置しているため，保険者の収支は赤字になっ てしまう。

そこで, リスク・タイプLとタイプHの存在割合が $\lambda: 1-\lambda(0 \leq \lambda \leq 1)$ であることを保険者が把握している場合，以下の加重平均保険料を設定し， 一括した保険契約を提示することによってプーリング均衡を困ることが考え

8）固定費用を無視し，かつ限界費用を一定とすると，定率負担と定額負担は同 じものと見なすことができる。 
られる。

$$
\bar{p}=\lambda p_{L}+(1-\lambda) p_{H}
$$

この場合，どちらのタイプも(16)式の保険料で提示される同一の保険契約に加 入することになる。低リスク・タイプ LからタイプHへの内部補助が生じて おり，リスク以上の保険料を支払わなくてはならない夕イプLが離れていく

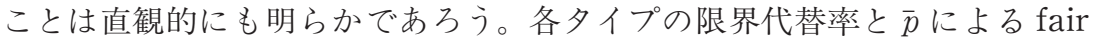
odds line の傾きを比較すると，効用を引き上げるべくタイプ Lがカバーを 減じ，タイプHはカバーを増やそうとする。その結果， $\bar{p}$ が引き上げられ， 前述の行動が促進され，終にはタイプLが保険に入る条件を満たさない状態 に陥ってしまう。市場に残るのはタイプHばかりとなり，市場での取引が成 立しなくなる。

逆選択への対処策としてはスクリーニング（自己選抜）による分離均衡が 挙げられる ${ }^{9)}$ 。前述のように, 保険者が 2 種類の保険契約を提示すると, 両 タイプともに保険料の安いタイプL向けの契約に引きつけられてしまう。そ こで，タイプ HがタイプLの保険契約を選択しないように，言い換えれば自 らのリスク・タイプ向けの保険契約を選択するように契約設計を工夫する点 がここでのアイデアである。図 4 に示される $E_{L}^{\prime}$ と $E_{H}$ が唯一の（ナッシ ユ）均衡である。タイプHの契約者は $E_{H}$ においてフルカバーを提示されて おり，その無差別曲線上にタイプL向けの契約である $E_{L}^{\prime}{ }^{\prime}$ あ゙る。よって， タイプHが $E_{L}^{\prime}$ に引きつけられることはない ${ }^{10)}$ ももちろん，いずれの契約 も各 fair odds line 上にあるため保険者の収支も均衡しており，他の保険者 が新たな契約を提示して利潤をあげることはできない。

ただし，罒からも明らかなように，タイプHの契約がフルカバーである一 方，タイプLに提示される契約は一部カバーに限定されている。また，タイ プLの割合が十分に大きい場合など, この分離均衡がいつも存在するとは限

9) Rothschild \& Stiglitz (1976)。

10) $E_{H}$ と $E_{L}^{\prime}$ は無差別である。 
官民の役割分担に関する情報の経済学からのアプローチ

図 4 。スクリーニングによる分離均衡

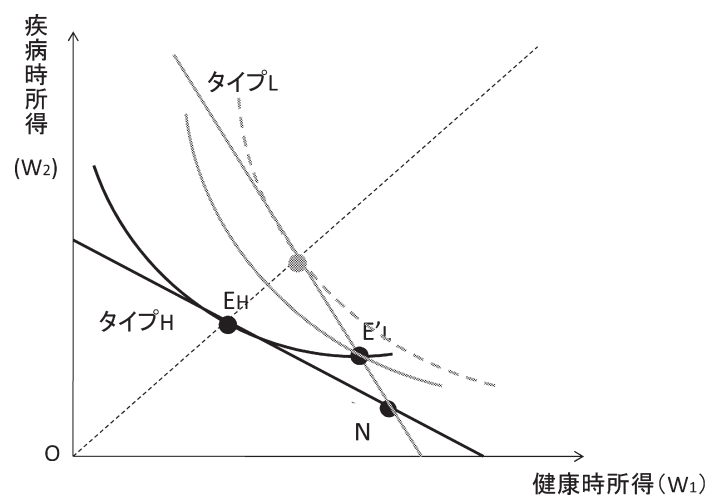

らないため注意を要する ${ }^{11)}$ 。そして逆選択の対処策としては，スクリーニン グによる分離均衡以外にもシグナリングや強制保険も挙げられる ${ }^{12)}$ 。

\section{5 。平均保険料を用いた強制保険}

本節では，前節を踏まえて公的医療保障制度を意識した強制保険に関する 議論を整理する。公的医療保険の第一義的な特徵は強制保険とされている ${ }^{13)}$ 。 低リスク・タイプLをいわば強制的に加入させるという逆選択の解消を理由 として公的医療保険制度が正当化される場合がある。加えて, 誰でも利用可 能になることから，所得格差に起因する医療サービスへのアクセスが確保さ れ，公平性の面で有効とされる ${ }^{14)}$

図 5 は，前節(16)式で定義された加重平均保険料 $\bar{p}$ を用いた強制保険を導 入した様子を示している。ここではフルカバーの契約 $E_{C}$ に両タイプを強制 加入させることによってプーリング均衡の安定を図っている。平均保険料に

11）漆編（1988）第 4 章 $\mathrm{p} 76$ 。

12）強制保険については次節参照。

13）西村他編（2006）第 6 章 $\mathrm{p} 124$ 。第二は公定価格の適用としている。

14）ただし，高リスク・タイプであるほど低所得者である状況では，逆選択とリ スク選択を根拠とする強制保険の導入意義は全く異なってくる。 
図 5 。平均保険料による強制保険(1)

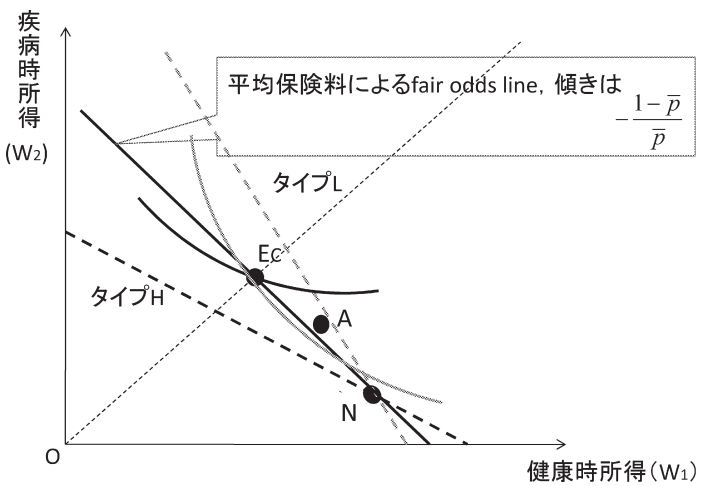

よる fair odds lineは保険未加入時を表す点 $N$ を通り，両タイプの fair odds lineの間に位置している。またこの線上で契約を提示していることか ら保険者の収支は均衡している。

もし強制保険でないならば，たとえば図 5 の点 $A$ の契約を提示する保険 者が出てくるであろう。効用が増すため夕イプLの契約者が点 $A$ を選択し, 提示した保険者も正の利潤を獲得することができるからである。また，タイ

図 6 。平均保険料による強制保険(2)

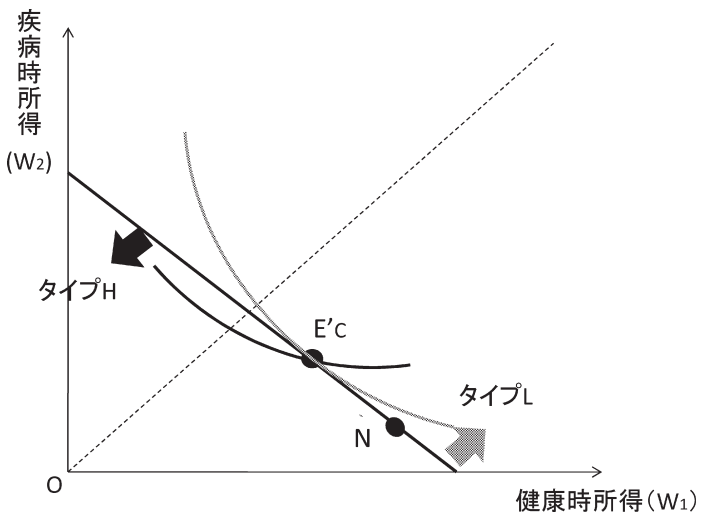


官民の役割分担に関する情報の経済学からのアプローチ

プLの効用を上げるために, fair odds line 上の $E_{C}$ より右下の $E^{\prime}{ }_{C}$ で強制 加入させることも考えられる (図 6 参照)。この場合, 夕イプ Lの効用が上 昇する一方で，タイプHの効用は下落し，一部カバーの契約になる。

本節の終わりにいくつか留意点を述べたい。プーリング均衡によって逆選 択の問題は解消したとしても，モラル・ハザードの問題は依然として残る。 さらに，明らかにタイプLから Hへの内部補助が行われているため，この意 味で非効率も生じている。また, 強制保険の「保険者」が国・政府である根 拠は明らかではない。

\section{6. 官民の役割分担}

ここまでは「民」のみ，もしくは「官」のみに焦点を当てた議論であった。 本節では，医療保障制度における官民の望ましい役割分担を模索していく。

そもそも望ましい役割分担を探るにあたっては何らかの基準が必要とされ る。基準としては効率性と公平性の二つが挙げられよう。効率性は資源の有 効配分を指し，公平性は経済的な意味での平等に近い概念だと考えられる。 本節では，前者についてはパレート改善，後者については社会的厚生関数を 通じて役割分担の在り方へアプローチを試みる。

\section{6-1. パレート改善例}

本小節では，官と民での保険契約提示により，いずれか一方だけで提示す る場合からパレート改善が達成される一例を紹介する。すなわち，誰の効用 も下げることなく少なくとも一人の効用を引き上げ，資源配分の改善を達成 するのである。ここから官民の役割分担の意義を見出すことができ，また役 割分担の在り方の手掛かりが得られる。な扮議論はDalby（1981）および Zweifel（2000）に沿う ${ }^{15)}$ 。

前節同様に，低リスク・タイプ Lと高リスク・タイプ $\mathrm{H} の 2$ 種類が存在し ており，その存在割合入は分かっているものとする。このとき, 図 7 にパ

15）諏澤（2011）もこの視点から官民の役割分担について論じている。 
保険学雑誌 第 625 号

レート改善が示されている。まず線分 $N N^{\prime}$ は(16)式で与えられる加重平均保 険料 $\bar{p}$ を用いた fair odds lineの一部である。この $N^{\prime}$ までのカバーを公的 医療保険制度が提供する。 $N^{\prime}$ は $N$ の左上に位置しているため, $N$ に比べ て健康時所得が減じられ，疾病時所得が増加している。これは公的医療保険 への強制加入を課している現れである。そして， $N^{\prime}$ を超えたカバーを民間 保険が提供する。 $N^{\prime}$ を起点としてタイプ Lとタイプ Hの新たな fair odds line が実線で左上に向かって引かれている（それぞれグレーと黒の直線）。 これらの fair odds line を基に, 前節のスクリーニングによる分離均衡が展 開され，均衡点がそれぞれ $E^{\prime \prime}{ }_{L}$ と $E_{H}^{\prime}$ で示されている。民間保険が担当す るカバー領域ではナッシュ均衡が成立しているため，新たな契約の提示はな されない。また，fair odds line 上にあるため，公的医療保険者と民間医療 保険者いずれも収支は均衡状態にある。

\section{図 7 。官民の役割分担}

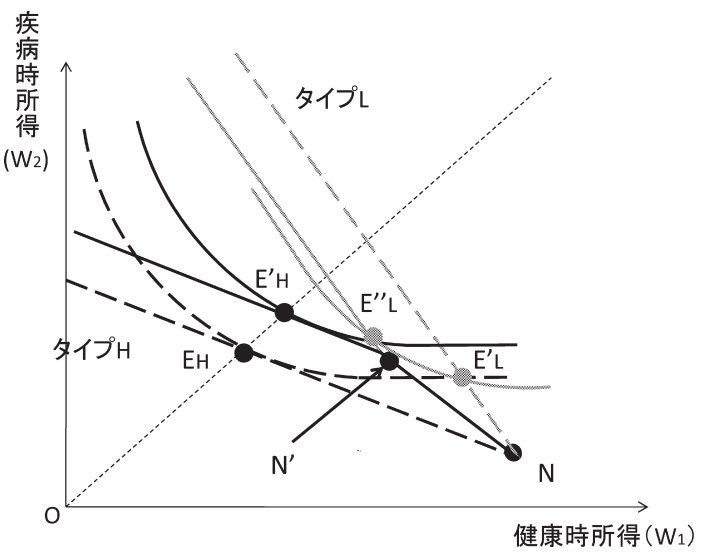

今, 公的医療保険のカバー範囲 $N^{\prime}$ を図 6 の $E^{\prime}{ }_{C}$ の水準とする。図 7 を民 だけの分離均衡（図 4 ）および官だけの平均保険料を用いた強制保険（図 6 ）と比較すると，パレート改善が達成されていることが確認できる。つま 
官民の役割分担に関する情報の経済学からのアプローチ

ク，図 4 と図 6 のいずれよりも図 7 の $E^{\prime \prime}{ }_{L}$ と $E_{H}^{\prime}{ }_{H}$ は効用が等しいか増加し ているかのどちらかである。

ここでは，ある範囲までを官が提供し，それ以上を民が提供しているため， 民間保険は限定的ながら補完機能，補足機能あるいは二重機能の役割を担っ ている。他の機能である代替機能や定額給付機能もある程度このモデルで説 明可能だと思われるが，この点は今後の課題としたい。

\section{6 - 2. 社会的厚生関数の適用}

医療分野および社会保険に関する政策決定の場では公平性がキーワードと なることが多い。民間だけに医療保険を任せて市場で医療サービス価格が決 定されるならば，医療アクセスの公平性が損なわれかねない。公平性を測る 道具として，あるいは不平等をどの程度解消すべきかを判断する際の目安と して社会的厚生関数が利用されることがある ${ }^{16)}$ 。本小節では社会的厚生関数 の医療保険制度への適用について若干の考察を行う。

そもそも，社会的厚生関数は社会構成員 $n$ 人の効用を用いて以下を満た す関数として定義される。

$$
S W=f\left(U_{1}, U_{2}, \ldots, U_{n}\right), \frac{\partial f}{\partial U_{i}} \geq 0 \quad(i=1,2, \ldots, n)
$$

代表的な関数形とて，ベンサム型の功利主義的社会的厚生関数とロールズ型 の社会的厚生関数が挙げられる ${ }^{17)}$ 。前者は社会的厚生が構成員の効用の和と して与えられ，個々の効用ではなく社会全体の効用を対象とするため，公平 性を追求しているとは言い難い。一方後者のロールズ型は $S W=\min \left\{U_{1}\right.$, $\left.U_{2}, \ldots, U_{n}\right\}$ で与えられ，政策によって最低水準の効用の引き上げを目的と することから公平性を追求するものと言える。

社会的厚生関数を医療保険制度に適用する簡素なアイデアとしては，期待 効用を各リスク・タイプの存在割合で加重し, それらの和を社会的厚生と見

16）所得の再分配に関する議論で持ち出されることが多い。

17）この他にバーグソン＝サミュエルソン型やナッシュ型もある。 
保険学雑誌 第 625 号

なして最大化を図る方法が考えられよう。すなわち， $S W=\lambda E U_{L}+(1-$ i) $E U_{H}$ と設定する。これまでのモデルに沿うならば，健康時所得と疾病時 所得を表現し，社会的厚生を最大にするような官民のカバー範囲を求めるこ とになる。しかしながら技術的な問題の前に，政策決定のために如何なる社 会的厚生関数を選択すべきか，という根本的な問題がある ${ }^{18)}$ 。それには社会 構成員の効用の測定はもちろんのこと, 社会の価値観, 公平観, 倫理観, 政 治的要素などを加味して決定する必要がある。

\section{7 . 考察と課題}

モラル・ハザードの影響の抑制は制度設計に依存しており，第 3 節では自 己負担による医療リスクの頻度や強度の改善を示した。そこでは自己負担率 を上げることによって，契約者にコントロール可能な範囲で疾病率や医療サ 一ビス量を引き下げるインセンティブが働いていた。しかし自己負担の引き 上げは医療アクセスを過度に抑え込んでしまう危険性もある。さらに，自己 負担の調整は特定の医療サービスだけではなく，医療全体の視点が必要不可 欠である。

官民の役割分担については，まず漆編（1998）でも指摘されているように， 民間保険が未成熟である場合には，官による民のクラウド・アウトが懸念さ れる ${ }^{19)}$ 。民間保険が（一層）成熟化するためには多様な機能が期待されよう。 また，官の介入として，所得再分配を一義的に置くのであれば，課税や補助 金を通じて公的医療保険制度と同様の効果を得ることも可能である。どちら が望ましい介入手段であるかは熟慮する余地がある。

残された大きな課題としては以下が挙げられる。本稿では保険者と契約者 間の情報の非対称性のみを扱ったが，第 1 節で述べた医療保険市場の特徵の 一つ，すなわち医療サービスの高度な専門性に起因する医師と契約者（患

18）当該分野での社会的厚生関数推計も行われている。たとえば，Dolan (1998)。

19）漆編（1988）第 4 章 $\mathrm{p} 87$ 。 
官民の役割分担に関する情報の経済学からのアプローチ

者）間の情報の非対称性もまた顕著である。この非対称性も本来考慮しなが ら，医師や医療機関を含めた行動分析が必要である。ここには診療報酬体系 の設計も梁く関連してこよう ${ }^{20)}$ 。また，本稿では理論アプローチに終始した が，もちろん理論を補強するデー夕分析も大いに必要とされる。

(筆者は福岡大学商学部准教授)

\section{参考文献}

漆博雄編（1998）『医療経済学』東京大学出版会。

小塩隆士（2005）『社会保障の経済学 第 3 版』日本評論社。

河口洋行（2012）『医療の経済学 第 2 版』日本評論社。

諏澤吉彦（2011）「医療保険市場に㧍ける民間保険のあり方に関する考察一公的保

険と民間保険の役割分担に関する分析モデルの検討を中心に一」『生命保険論

集』Vol.174，pp.1-26。

中泉真樹（2004）「情報の非対称性のもとでの医療技術の選択と最適医療保険」

『医療と社会』Vol.14 No.3 pp.111-125。

西村周三・田中滋・遠藤久夫編（2006）『医療経済学の基礎理論と論点』勁草書房。 森平爽一郎・米山高生監訳（2012）『統合リスクマネジメント』中央経済社

(Doherty, N. A. (2000) Integrated Risk Management, McGraw-Hill).

Akerlof, G. A. (1970), "The Market for Lemons," Quarterly Journal of Economics, 84, pp. 488-500.

Arrow, K. J. (1963), "Uncertainty and the Welfare Economics of Medical Care," American Economic Review, Vol.53, pp.941-973.

Crocker, K. J. and Snow, A. (1985), "The Efficiency of Competitive Equilibria in Insurance Markets with Asymmetric Information," Journal of Public Economics, Vol.26, pp. 207-219.

Dahlby, B. G. (1981), "Adverse Selection and Pareto Improvements through Compulsory Insurance," Public Choice, Vol.37, pp.547-558.

Dolan, P. (1998), "The Measurement of Individual Utility and Social Welfare," Journal of Health Economics, Vol.17, pp.39-52.

Neudeck, W. and Podczeck, K. (1996), "Adverse Selection and Regulation in Health Insurance Markets," Journal of Health Economics, Vol.15, pp. 387-408.

20） 医師と患者間の情報の非対称性を扱ったモデル分析として，たとえば中泉 (2004)。 
Rothschild, M. and Stiglitz, J. (1976), "Equilibrium in Competitive Insurance Markets: An Essay on the Economics of Imperfect Information," Quarterly Journal of Economics, Vol.90, pp.629-649.

Zweifel, P. (2000), "The Division of Labor between Private and Social Insurance," in Georges Dionne eds., Handbook of Insurance, Kluwer Academic Pub., pp.933-966. 